\title{
CHEMISTRY OF UNSATURATED ARENETRICARBONYLCHROMIUM COMPOUNDS. PART 3. SYNTHESIS, CHARACTERISTICS AND SPECTROSCOPIC RESEARCH OF $\eta^{6}$-(ARENE)TRICARBONYLCHROMIUM DERIVATIVES OF ISOXAZOLIDINES
}

\author{
A.N. Artemov, zarovkinan@mail.ru \\ E.V.Sazonova, zarovkinan@mail.ru \\ N.Yu. Zarovkina, zarovkinan@mail.ru \\ V.I. Faerman, vvllff@rambler.ru \\ Lobachevsky State University of Nizhny Novgorod, Nizhny Novgorod, Russian Federation
}

The series of $\eta^{6}$-(arene)tricarbonylchromium complexes of isoxazolidines has been obtained by 1,3-dipolar cycloaddition. The obtained compounds have been investigated by IR spectroscopy, ${ }^{1} \mathrm{H}$ NMR spectroscopy and mass spectrometry. It has been shown that $\mathrm{Cr}(\mathrm{CO})_{3}$ group significantly influences the structure and spectral characteristics of synthesized heterocycles.

Keywords: 1,3-dipolar cycloaddition, nitrone, isoxazolidine, $\eta^{6}$-(arene)tricarbonylchromium, IR spectroscopy, ${ }^{I}$ H NMR spectroscopy, mass spectrometry.

\section{Introduction}

The reaction of 1,3-dipolar cycloaddition are of fundamental importance, from theoretical and practical points of view alike, it is a classical synthesis method for five-membered heterocyclic compounds. One of its essential parts is the interaction between nitrones and alkenes leading to formation of isoxazolidines [1-3]. The enormous number of various functionally substituted compounds notwithstanding, the $\pi$-complexes containing tricarbonylmetal groups are practically absent among them. Fundamental interest in $\pi$-complexes of such kind is in establishment of the influence of electron and steric factors peculiar to $\eta^{6}$-(arene)tricarbonyl group upon the selectivity of 1,3-dipolar addition and the structure of the formed products.

Recently we have reported [4-6] that the introduction of $\mathrm{Cr}(\mathrm{CO})_{3}$ group into phenyl rings of both nitrone and alkene leads to significant increase of regio- and diasterioselectivity for the 1,3-dipolar cycloaddition reactions, at that nothing but $\mathrm{C}(3), \mathrm{C}(5)$-substituted isoxazolidines with predominantly cisstructure is formed. In the present paper we describe the investigation of these compounds in detail, using various physicochemical methods of analysis.

\section{Results and Discussion}

The initial isoxazolidines have been obtained in accordance with the previously developed procedure $[4,5]$ (reactions (1)-(4), Scheme 1), in which a number of free and coordinated nitrones have been used as dipoles in the 1,3-dipolar cycloaddition reactions:

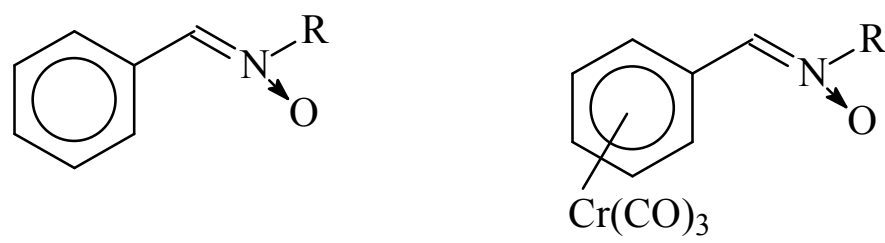

$$
\mathrm{R}=\mathrm{CH}_{3}(\mathbf{a}) ; \mathrm{t}-\mathrm{C}_{4} \mathrm{H}_{9}(\mathbf{b}) ; \mathrm{C}_{6} \mathrm{H}_{5}(\mathbf{c})
$$

Styrene and $\eta^{6}$-(styrene)tricarbonylchromium have been used of in this reaction as dipoles (Scheme 1) [7]. 

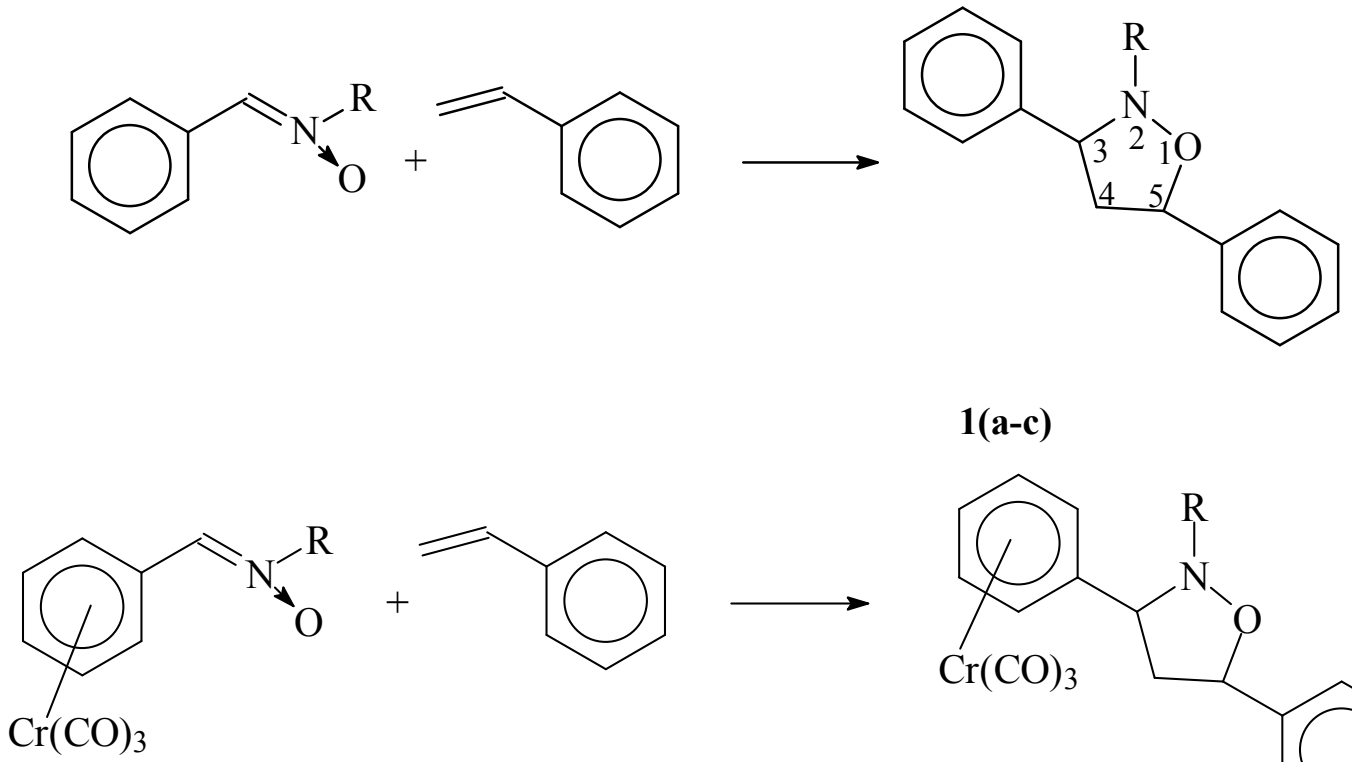<smiles>C=Cc1ccccc1</smiles><smiles>[R]N1OC(c2ccccc2)CC1c1ccccc1C(C)(C)C(=O)[O-]</smiles>

$$
\text { 2(a-c) }
$$<smiles>[R]/[N+]([O-])=C/c1ccccc1</smiles><smiles></smiles><smiles>C=Cc1cccc(C(C)(C)C(C)(C)C(C)(C)C)c1</smiles><smiles>[R]N1OC(c2ccccc2)CC1c1ccccc1</smiles>

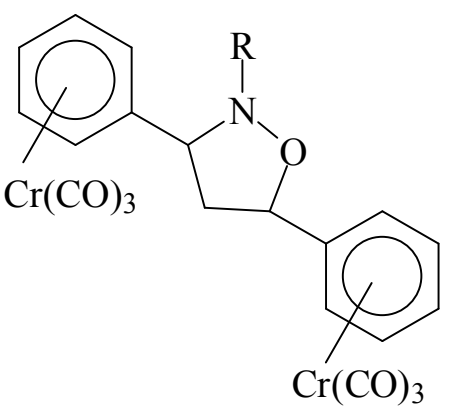

$$
\mathrm{R}=\mathrm{CH}_{3}(\mathbf{a}) ; \mathrm{t}-\mathrm{C}_{4} \mathrm{H}_{9}(\mathbf{b}) ; \mathrm{C}_{6} \mathrm{H}_{5}(\mathbf{c})
$$

Scheme 1

All the processes, except reaction (1), have led to formation of isoxazolidines containing $\mathrm{Cr}(\mathrm{CO})_{3}$ groups. The obtained arenetricarbonylchromium complexes of those heterocycles look like yellow crystalline substances that are comparatively stable in air. All isoxazolidines are isolated in the pure state and investigated using various physicochemical methods of analysis.

The reaction conditions and some properties of isoxazolidines $\mathbf{2 a - c - 4 a - c}$ are represented in Table 1. 


\section{Organometallic chemistry}

The reaction conditions and some properties of $\pi$-complexes of isoxazolidines $2 a-c-4 a-c$

\begin{tabular}{|c|c|c|c|c|}
\hline \multirow{2}{*}{ Compound } & \multicolumn{2}{|c|}{ Reaction conditions } & \multirow{2}{*}{ Yield, $\%$} & \multirow{2}{*}{ M.p., ${ }^{\circ} \mathrm{C}$} \\
\cline { 2 - 3 } & Time, $\mathrm{h}$ & Temperature, ${ }^{\circ} \mathrm{C}$ & 25 & $94-95$ \\
\hline $\mathbf{2 a}$ & 6 & 90 & 30 & $40-41$ \\
\hline $\mathbf{2 b}$ & 6 & 90 & 62 & $121-122$ \\
\hline $\mathbf{2 c}$ & 6 & 90 & 66 & $91-92$ \\
\hline $\mathbf{3 a}$ & 40 & 105 & 47 & $104-105$ \\
\hline $\mathbf{3 b}$ & 40 & 105 & 42 & $112-113$ \\
\hline $\mathbf{3 c}$ & 40 & 105 & 20 & $155-156$ \\
\hline $\mathbf{4 a}$ & 40 & 80 & 36 & $136-137$ \\
\hline $\mathbf{4 b}$ & 40 & 80 & 38 & $132-133$ \\
\hline $\mathbf{4 c}$ & 40 & 80 & \\
\hline
\end{tabular}

The IR spectra of each $\pi$-complex (2a-c - 4a-c) show the expected pair of stretching vibrations from $A_{1}$ and $E$ bands of tricarbonylchromium group. Repositioning of these bands in the spectrum often provides valuable information concerning the electronic effects of a system. From the measurement results presented in Table 2 it follows that the values of stretching $v_{c o}$ vibrations of the complexes suffer comparatively small though reasonably regular changes that far exceed experimental error, under the influence of a heterocyclic ring as a substituent. Repositioning of stretching $v_{\mathrm{co}}$ vibrations inside the isostructural series can be considered as the result of electron influence of the heterocyclic ring. It is known $[8,9]$ that the frequencies of carbonyl vibrations in IR spectra of the compounds of $\eta^{6}-\left(\mathrm{C}_{6} \mathrm{H}_{5} \mathrm{X}\right) \mathrm{Cr}(\mathrm{CO})_{3}$ type are sensitive to electronic effects of the substituent $\mathrm{X}$. Thus, $\pi$-donor groups, which increase the negative charge on the oxygen atom, shift the $v_{\mathrm{co}}$ vibrations towards increasing wavelengths. To the contrary, the substituents with acceptor properties produce the opposite effect, viz. heighten the frequencies of stretching vibrations. Correlation of the stretching vibration frequencies in the IR spectra of the investigated series and the IR spectrum of $\eta^{6}$-(benzene)tricarbonylchromium $\left(v_{\mathrm{co}}=1972,1891 \mathrm{~cm}^{-1}\right)$ makes it easy to see that the isoxazolidine ring is a weak donor with respect to $\mathrm{Cr}(\mathrm{CO})_{3}$ group.

Another characteristic feature of IR spectra of some compounds in this series is considerable splitting of $v_{\text {co }}$ bands of degenerate carbonyl vibrations. Doubling of $E$ bands in IR spectra of carbonyl metal complexes is not anything exceptional, it is explained by violation of the $\mathrm{C}_{3 \mathrm{v}}$ rule - the local symmetry of tricarbonylchromium group. This rule holds quite well for the cases, in which it can be supposed that $\mathrm{M}(\mathrm{CO})_{3}$ group rotates freely and carbonyl groups do not interact with other parts of a molecule. Such splitting of $\mathrm{E}$ band for carbonyl vibrations has also been observed for many other complexes of transition metals, as an example, the substitution derivatives of $\eta^{5}$-(cyclopentadienyl)tricarbonylmanganese and-rhenium [8,9], as well as the series of $\eta^{6}$-(benzene)tricarbonylchromium [8]. Thus, in paper [10] it has been shown that $E$ band significantly splits for $\eta^{6}$-(arene)tricarbonlylchromium alcohols containing hydroxyl groups in $\alpha$-position in relation to $\pi$-arene ring $\left(\left(v_{\mathrm{co}}-\mathrm{A}_{1}: 1960, \mathrm{E}: 1870,1720 \mathrm{~cm}^{-1}\right)\right.$, while for the alcohols containing $\mathrm{OH}$ groups in $\beta$ - and $\gamma$-positions any similar splitting of bands of degenerate vibrations is nonexistent.

In order to establish why E bands broaden and split in the series of $\pi$-complexes of isoxazolidines, we carried out the investigation of IR spectra of these compounds in various media: in the solid state (in potassium bromide pellets), as well as in cyclohexane and carbon tetrachloride solutions. As Table 2 suggests, for the solid samples of compounds 2a-c - 3a-c intensive splitting of $E$ band is observed, in the case of $3 \mathbf{c}$ it reaches the difference of wavenumbers $\Delta(v(E))=47 \mathrm{~cm}^{-1}$. Carbonyl area in IR spectra of compound 3c is shown in Fig. 1. This appearance of the spectrum can be explained both by intermolecular interactions (crystalline factor) and by intramolecular interactions between one of carbonyl groups and the oxygen atom of the heterocyclic ring.

It is known that during transition from solid samples to solutions crystalline factors cease to act, which results in spectra with better resolution. As a rule, significant increase of the frequencies of carbonyl vibrations occurs at that (Table 2). By way of example, for isoxazolidine 3a the frequencies of symmetrical $v_{\mathrm{co}}$ vibrations $\left(\mathrm{A}_{1}\right)$ in cyclohexane and carbon tetrachloride solutions increase by $25 \mathrm{~cm}^{-1}$, while the frequencies of degenerate vibrations increase by $34 \mathrm{~cm}^{-1}$ on average, in each case they constitute only one unsplitted signal. 
The frequencies of the symmetric $\left(A_{1}\right)$ and asymmetric $(E)$ stretching carbonyl vibrations in IR-spectra of isoxazolidines cis-2-4

\begin{tabular}{|c|c|c|c|c|c|c|}
\hline \multirow{3}{*}{ Compound } & \multicolumn{6}{|c|}{$v_{\mathrm{co},} \mathrm{cm}^{-1}$} \\
\hline & \multicolumn{3}{|c|}{$\mathrm{A}_{1}$} & \multicolumn{3}{|c|}{$\mathrm{E}$} \\
\hline & $\mathrm{KBr}$ & n- $\mathrm{C}_{6} \mathrm{H}_{12}$ & $\mathrm{CCl}_{4}$ & $\mathrm{KBr}$ & $\mathrm{n}-\mathrm{C}_{6} \mathrm{H}_{12}$ & $\mathrm{CCl}_{4}$ \\
\hline $2 \mathbf{a}$ & 1956 & 1979 & 1975 & 1875,1862 & 1912 & 1905 \\
\hline $2 \mathbf{b}$ & 1961 & 1976 & 1972 & 1885,1871 & 1909,1903 & 1901 \\
\hline $2 c$ & 1957 & 1980 & 1976 & 1882,1865 & 1914,1905 & 1905 \\
\hline $3 \mathbf{a}$ & 1955 & 1980 & 1977 & 1894,1875 & 1912 & 1906 \\
\hline $3 b$ & 1951 & 1979 & 1975 & 1885,1872 & 1911 & 1904 \\
\hline $3 c$ & 1970 & 1981 & 1978 & 1904,1857 & 1914 & 1907 \\
\hline $4 a$ & 1953 & - & - & 1885,1877 & - & - \\
\hline $4 b$ & 1963 & - & - & 1886,1865 & - & - \\
\hline $4 c$ & 1961 & - & - & 1887,1870 & - & - \\
\hline
\end{tabular}

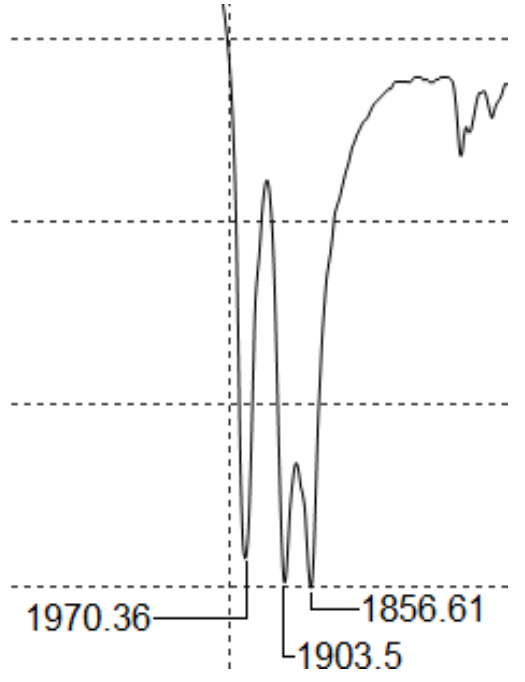

a)

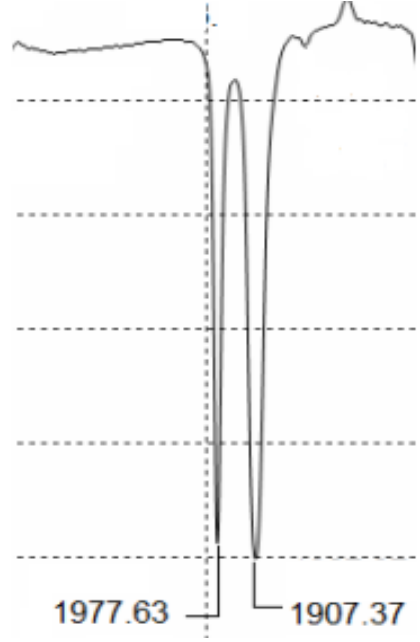

b)

Fig. 1. The IR-spectrum of isoxazolidine $3 \mathrm{c}$ in the area of carbonyl vibrations: $\mathrm{a}$ - in the tablet of $\mathrm{KBr}, \mathrm{b}-$ in the solution of $\mathrm{CCl}_{4}$

Therefore, owing to the investigation of IR spectra in crystalline state and in solutions it has been shown that splitting of the bands of degenerate vibrations, observed for the solid samples, does not take place in solutions, because of solvation of $\eta^{6}$-(arene)tricarbonylchromium complexes of isoxazolidines by the solvent molecules.

The structure and configuration of all obtained compounds have been established with the use of ${ }^{1} \mathrm{H}$ NMR spectroscopy as well. In the spectra of all complex isoxazolidines six groups of resonance signals are observed: from the protons of a substituent at the nitrogen atom $\left(\mathrm{CH}_{3}, \mathrm{t}-\mathrm{C}_{4} \mathrm{H}_{9}, \mathrm{C}_{6} \mathrm{H}_{5}\right)$, from the methylene protons at the fourth carbon atom of the heterocycle $(2 \mathrm{H}, \mathrm{C}(4))$, from the single protons of the ring $(1 \mathrm{H}, \mathrm{C}(3)$ and $1 \mathrm{H}, \mathrm{C}(5))$, as well as the protons of the free and coordinated phenyl rings (Table 3 and Experimental). The ${ }^{1} \mathrm{H}$ NMR spectroscopy data, represented in Table 3, unambiguously prove that the substituents in the isoxazolidine ring are located in positions 2,3,5. This assignment has been suggested on the basis of resonance position for two protons of the methylene group and their spin-spin interaction constants. If the configuration of the substituents in isoxazolidine is taken to be $2,3,4$, then in such NMR spectrum the complex multiplet in the area 4.0-4.5 ppm should be observed, which is actually observed for all 2,3,4-trisubstituted isoxazolidines. Instead of this, the spectra of all obtained coordinated compounds have two quite narrow multiplets in the area $\delta=2.2-3.5 \mathrm{ppm}$, peculiar to 2,3,5substituted isoxazolidines. 


\section{Organometallic chemistry}

Table 3

The chemical shifts and the view of NMR $\mathrm{H}^{1}$-spectra of the protons of heterocyclic rings of the isoxazolidines cis-2-4

\begin{tabular}{|c|c|c|c|}
\hline Compound & $2 \mathrm{H}(\mathrm{C}(4))$ & $\mathrm{HC}(3)$ & $\mathrm{HC}(5)$ \\
\hline $\mathbf{2 a}$ & $2.28,3.24(\mathrm{t} . \mathrm{d}, \mathrm{t} . \mathrm{d})$ & $3.78(\mathrm{t})$ & $5.27-5.38(\mathrm{~m})$ \\
\hline $\mathbf{2 b}$ & $2.18-2.52,3.20-3.44(\mathrm{~m}, \mathrm{~m})$ & $4.53(\mathrm{~d} . \mathrm{d})$ & $5.26(\mathrm{t})$ \\
\hline $\mathbf{2 c}$ & $2.39,3.15-3.53($ d.d.d, $\mathrm{m})$ & $5.04(\mathrm{~d} . \mathrm{d})$ & $5.13-5.33(\mathrm{~m})$ \\
\hline $\mathbf{3 a}$ & $2.29,3.22-3.29$ (d.d.d, $\mathrm{m})$ & $3.71(\mathrm{t})$ & $4.98(\mathrm{~d} . \mathrm{d})$ \\
\hline $\mathbf{3 b}$ & $2.19,3.16($ d.t, d.t) & $4.49(\mathrm{~d} . \mathrm{d})$ & $4.88(\mathrm{~d} . \mathrm{d})$ \\
\hline $\mathbf{3 c}$ & $2.37,3.37($ d.t, d.t) & $5.00(\mathrm{t})$ & $5.00(\mathrm{t})$ \\
\hline $\mathbf{4 a}$ & $2.31,3.43($ d.t, d.t) & $3.83(\mathrm{t})$ & $5.07(\mathrm{t})$ \\
\hline $\mathbf{4 b}$ & $2.26-2.50,3.14-3.70(\mathrm{~m}, \mathrm{~m})$ & $4.51(\mathrm{~d} . \mathrm{d})$ & $4.99(\mathrm{t})$ \\
\hline $\mathbf{4 c}$ & $2.41,3.40($ d.d.d, d.d.d) & $4.82-5.19(\mathrm{~m})$ & $7.09-7.46(\mathrm{~m})$ \\
\hline
\end{tabular}

Another important aspect of the structure of $\eta^{6}$-(arene)tricarbonylchromium complexes of isoxazolidines is the arrangement of the substituents in relation to the heterocyclic ring plane. Assignment of the studied compound to cis- or trans-series (in this case it means the relative position of substituents at $\mathrm{C}(3)$ and $\mathrm{C}(5)$ carbon atoms of the heterocyclic ring) can be obtained on the basis of the well-known Karplus relationship for vicinal proton-proton constants: $3 \mathrm{~J}_{\mathrm{H}-\mathrm{H}}=\mathrm{f}(\theta)$, also, mainly, from the analysis of qualitative difference of chemical shifts $(\Delta \delta)$ of methylene protons at atom $C(4)$.

In the case of cis-arrangement of the substituents at $\mathrm{C}(3)$ and $\mathrm{C}(5)$ of the isoxazolidine ring, chemical shifts of protons $\mathrm{H}_{\mathrm{A}}$ and $\mathrm{H}_{\mathrm{B}}$ (Fig. 2) strongly differ, as $\mathrm{H}_{\mathrm{A}}$ interacts only with the protons that lie on the same side with it in relation to the heterocyclic ring plane, while $\mathrm{H}_{\mathrm{B}}$ interacts with the protons on the other side of the cycle. In this case the difference of chemical shifts usually falls within 0.7-1.2 ppm.
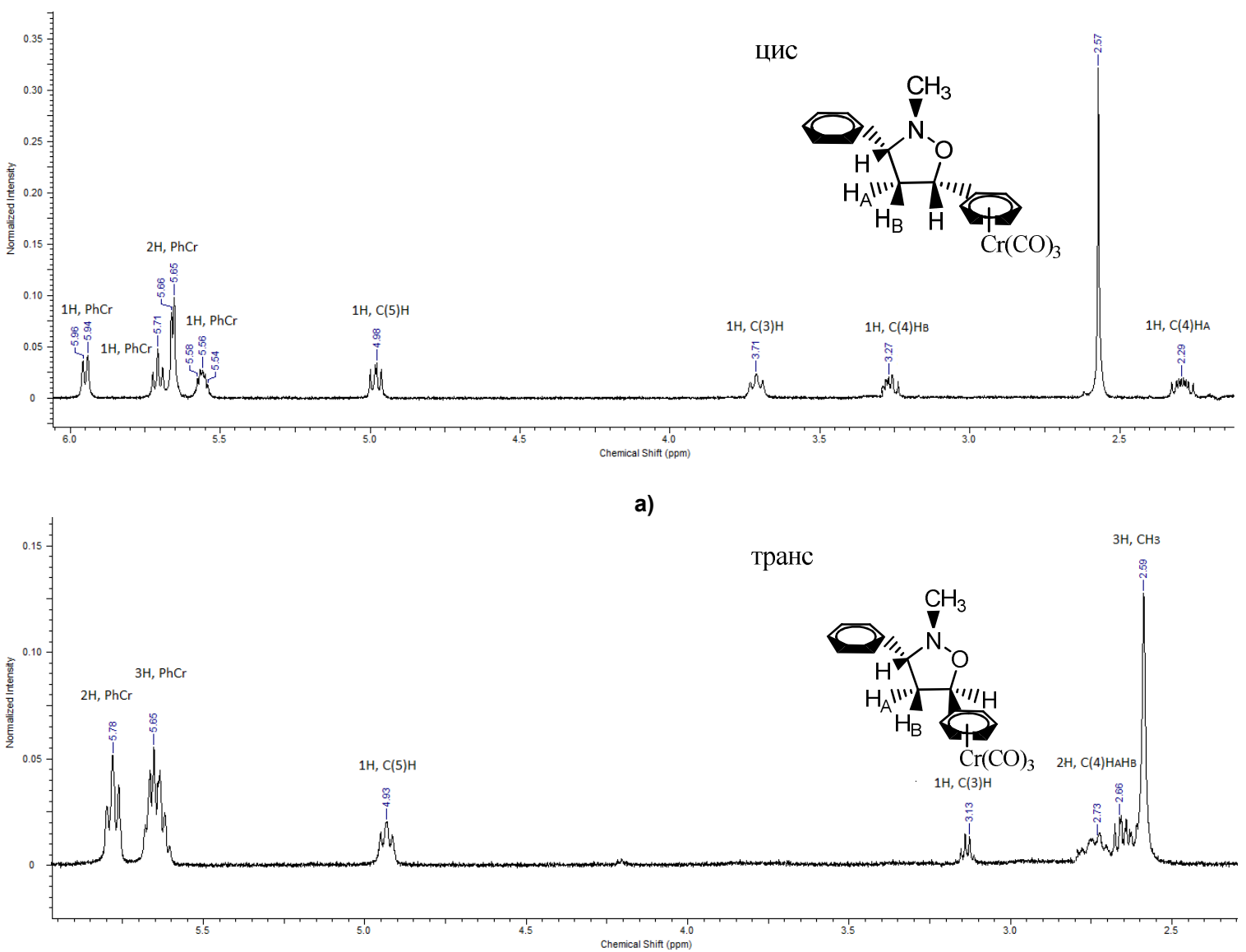

b)

Fig. 2. The fragments of NMR $H^{1}$-spectra $\left(400 \mathrm{MHz}\right.$, acetone- $\left.\mathrm{d}_{6}\right)$ of isoxazolidines cis-3a (a) and trans-3a (b) 
The interaction of protons $\mathrm{H}_{\mathrm{A}}$ and $\mathrm{H}_{\mathrm{B}}$ with the protons at carbon atoms $\mathrm{C}(3)$ and $\mathrm{C}(5)$ in the case of transarrangement of the substituents is symmetrical, that is, the values of their screening are close and equal $0.2-$ $0.3 \mathrm{ppm}$, sometimes one complex multiplet can be observed. Indeed, comparison of the spectra represented in Fig. 2 shows that the abovementioned rule is valid for them. Trans-2-methyl-5- $\eta^{6}-$ (phenyltricarbonylchromium)-3-phenylisoxazolidine (trans-3a), which is absent in Table 3, has been obtained with low yield as a by-product of the reaction between C-phenyl-N-methylnitrone and $\eta^{6}$ (styrene)tricarbonylchromium (ref. Experimental section), it has been separated from its mixture with cis-3a with the use of column chromatography on silica gel (by hexane/ethylacetate $=4: 1$ as the eluent). As can be seen from Fig. 2, the spectrum of cis-3a isomer illustrates the strong magnetic nonequivalence of two protons located at $\mathrm{C}(4)\left(\Delta \delta_{\mathrm{A}, \mathrm{B}} \sim 0.97 \mathrm{ppm}\right)$, which proves the cis-configuration of this isomer. At the same time trans3a isomer has one broad unresolved multiplet in the range 2.62-2.79 ppm. Therefore, ${ }^{1} \mathrm{H}$ NMR spectra make it possible not only to establish the composition of the obtained components, but also to prove their spatial structure unambiguously. The same purpose is served by mass spectra of these complexes.

For the obtained series of isoxazolidines with tricarbonylchromium groups the electron impact mass spectra have been registered and their fragmentation has been studied. As in the case of other carbonyl complexes of transition metals, the primary fragmentation consists in dissociation of three carbonyl groups that occurs in stages, at that the successful removal of the first $\mathrm{CO}$ group from the molecular ion $[\mathrm{M}]^{+}$brings leads to corresponding decrease in dissociation energy of the remaining $\mathrm{M}-\mathrm{CO}$ bonds. It is expressed in increasing intensity of the peaks in this sequence:

$$
[\mathrm{M}-\mathrm{CO}]^{+}<[\mathrm{M}-2 \mathrm{CO}]^{+}<[\mathrm{M}-3 \mathrm{CO}]^{+}
$$

Indeed, all obtained isoxazolidine complexes form molecular ions $[\mathrm{M}]^{+}$, which are principally transformed into fragments $[\mathrm{M}-3 \mathrm{CO}]^{+}$by way of elimination of three carbon monoxide molecules, either simultaneously or sequentially in the fast two-stage process:

$$
[\mathrm{M}]^{+} \rightarrow[\mathrm{M}-\mathrm{CO}]^{+} \rightarrow[\mathrm{M}-2 \mathrm{CO}]^{+} \rightarrow[\mathrm{M}-3 \mathrm{CO}]^{+}
$$

After elimination of three $\mathrm{CO}$ groups (fragment $\left[\mathrm{F}_{1}\right]^{+}$) the disintegration of the heterocyclic ring follows, essentially into two particles with formation of fragment ions $\left[\mathrm{F}_{2}\right]^{+}$, which correspond to retrodisintegration (Scheme 2):

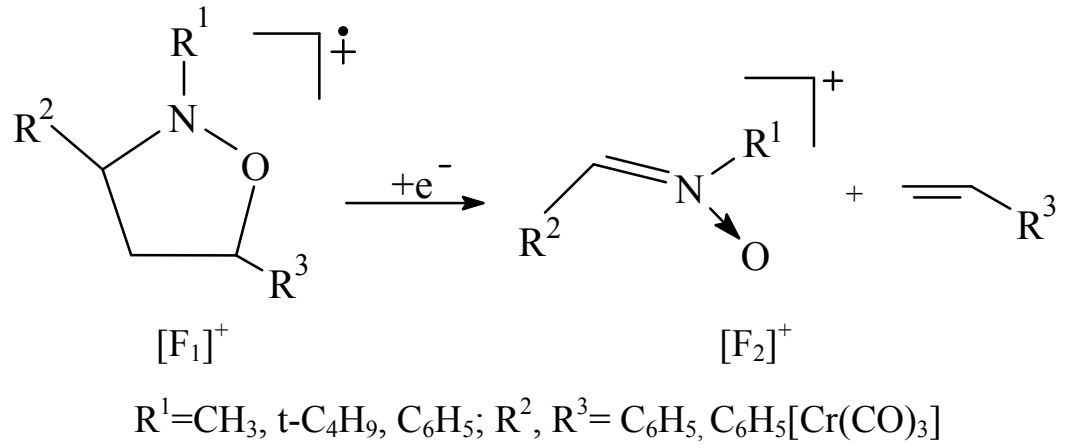

Scheme 2

Previously it has been shown that cis-2-methyl-3,5-diphenylisoxazolidine is ionized at electron impact with the formation of molecular ion $[\mathrm{M}]^{+}=239(24 \%)$, with the most intensive fragment ion in the spectrum $[\mathrm{F}]^{+}=135(100 \%)$. Fragmentation of this compound can be represented by the following simple scheme 3.

Introduction of $\mathrm{Cr}(\mathrm{CO})_{3}$ groups into isoxazolidines decidedly complicates the pattern of disintegration through appearance of additional peaks as the result of sequential elimination of carbon monoxide, as well as specific interaction of the metal. It is known that the primary ionization of a compound usually proceeds by way of the detachment of an electron from the higher bonding orbital of the organometallic complex, which is of predominantly metal character. That is why during disintegration of the molecular ion the charge usually remains on the metal-containing fragment. So the greater part of ion current consists of metal-containing ions. 


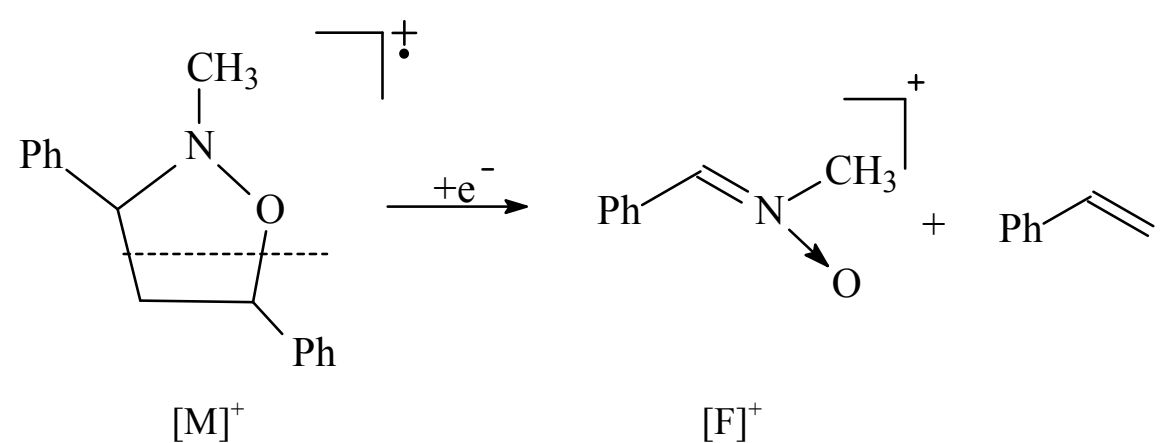

Scheme 3

Investigation of the influence of $\mathrm{Cr}(\mathrm{CO})_{3}$ groups upon the fragmentation process for isoxazolidines under electron impact has shown that the peaks of molecular ions have low intensity; much more intensive are the peaks of ions $\left[\mathrm{F}_{1}\right]^{+}$that correspond to the molecular ion after elimination of three carbonyl groups $[\mathrm{M}-3 \mathrm{CO}]^{+}$, as well as the ions resulting from disintegration of the heterocyclic ring. Just as with uncoordinated isoxazolidines the main (the most intensive) peaks in the mass spectra of all the studied compounds correspond to fragment ions $\left[\mathrm{F}_{2}\right]^{+}$, which are formed after disintegration of $\left[\mathrm{F}_{1}\right]^{+}$with elimination of styrene molecule. The direction of the following fragmentation depends on the structure of the formed ion. In a general way the fragmentation of $\eta^{6}$-(arene)tricarbonylchromium complexes of isoxazolidines can be represented by the dissociative scheme 4 .

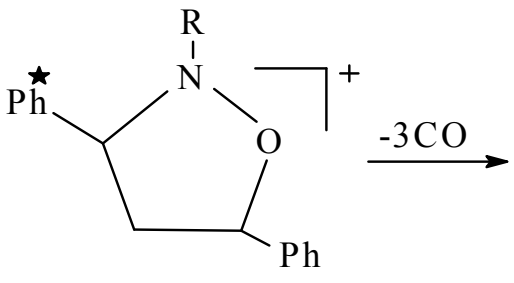

$[\mathrm{M}]^{+}$<smiles>[R]N1OC(c2ccccc2)CC1[PH2+]C</smiles>

$\left[\mathrm{F}_{1}\right]^{+}$<smiles>[R]N1[CH-]C(C)[C@H](c2ccccc2)[C@H](C)[C@H]1c1ccccc1</smiles>

$\left[\mathrm{F}_{1}\right]$<smiles>[R]/[N+](=C\c1ccccc1)O[CH2-]</smiles>

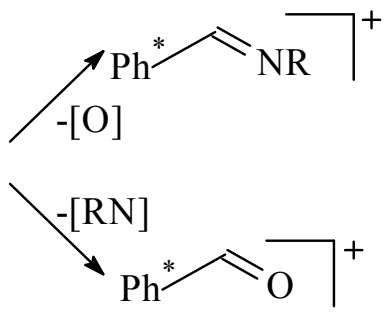

$\left[\mathrm{F}_{2}\right]$

here $\mathrm{Ph} \star=\mathrm{C}_{6} \mathrm{H}_{5}\left[\mathrm{Cr}(\mathrm{CO})_{3}\right], \mathrm{Ph}^{*}=\mathrm{C}_{6} \mathrm{H}_{5} \mathrm{Cr}, \mathrm{R}=\mathrm{CH}_{3}, \mathrm{t}-\mathrm{C}_{4} \mathrm{H}_{9}, \mathrm{C}_{6} \mathrm{H}_{5}$; the masses of the corresponding ions and their intensities are shown in Table 4

\section{Scheme 4}

For example, in the mass spectrum of 2-methyl-3- $\eta^{6}$-(phenyltricarbonylchromium)-5phenylisoxazolidine (2a) (Fig. 3, Table 4) there is the peak of the molecular ion $[\mathrm{M}]^{+}=375(1.2 \%)$, as well as the peaks corresponding to elimination of $\mathrm{CO}$ molecules. The peak of $\left[\mathrm{F}_{2}\right]^{+}$with $\mathrm{m} / \mathrm{z}=187$ $(100.0 \%)$ is the maximal; it forms from $\left[\mathrm{F}_{1}\right]^{+}$when neutral styrene $\left(\mathrm{C}_{8} \mathrm{H}_{8}\right)$ is removed from it. In its turn $\left[\mathrm{F}_{2}\right]^{+}$is subject to further disintegration by way of donor-acceptor bond $\mathrm{N} \rightarrow \mathrm{O}$ with removal of the oxygen atom and formation of $\left[\mathrm{F}_{3}\right]=171(16.0 \%)$ (Scheme 5), and also as the result of rearrangement with removal of particle $\left[\mathrm{NCH}_{3}\right]$ and formation of ion $\left[\mathrm{F}_{4}\right]^{+}$. 


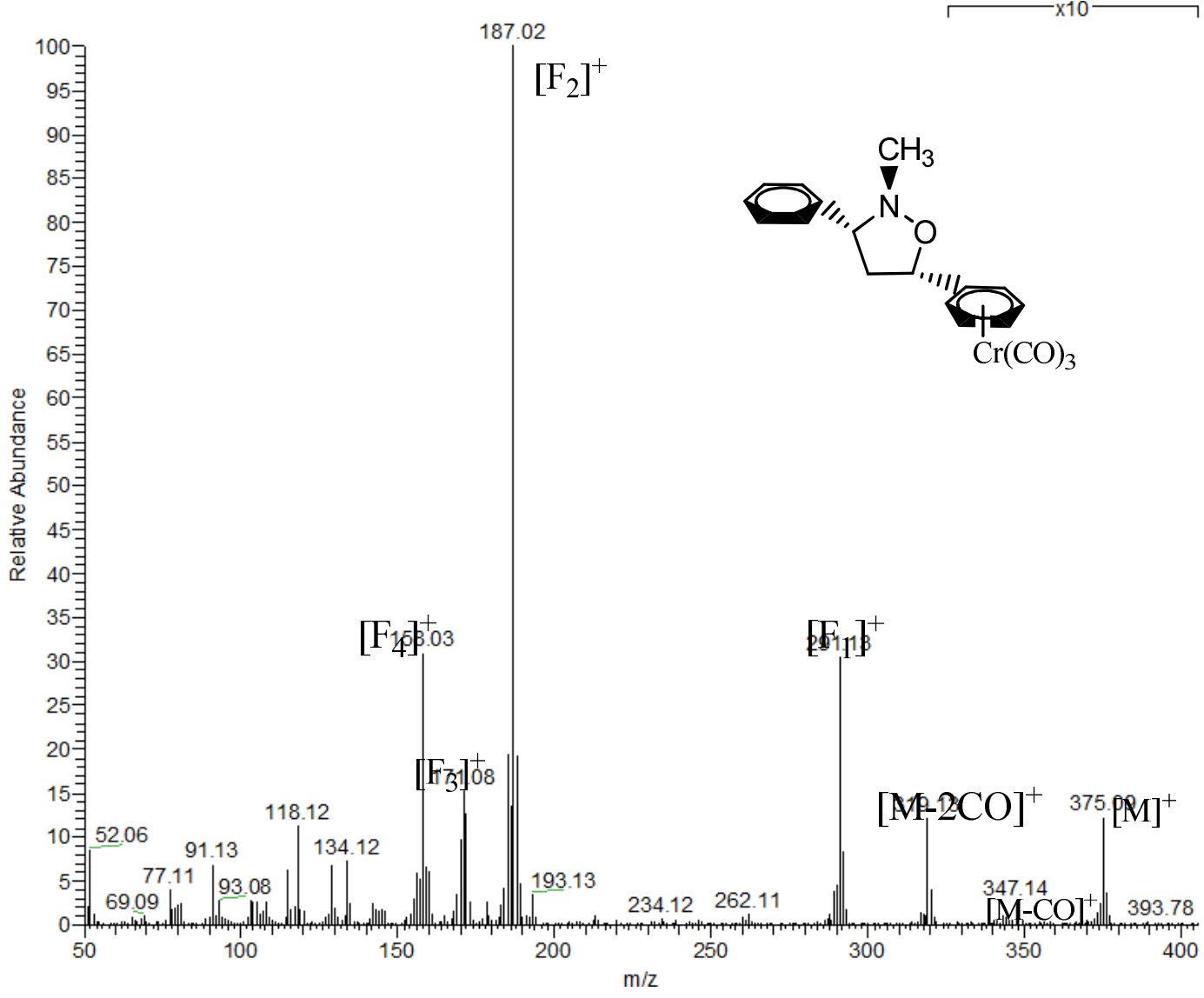

a)

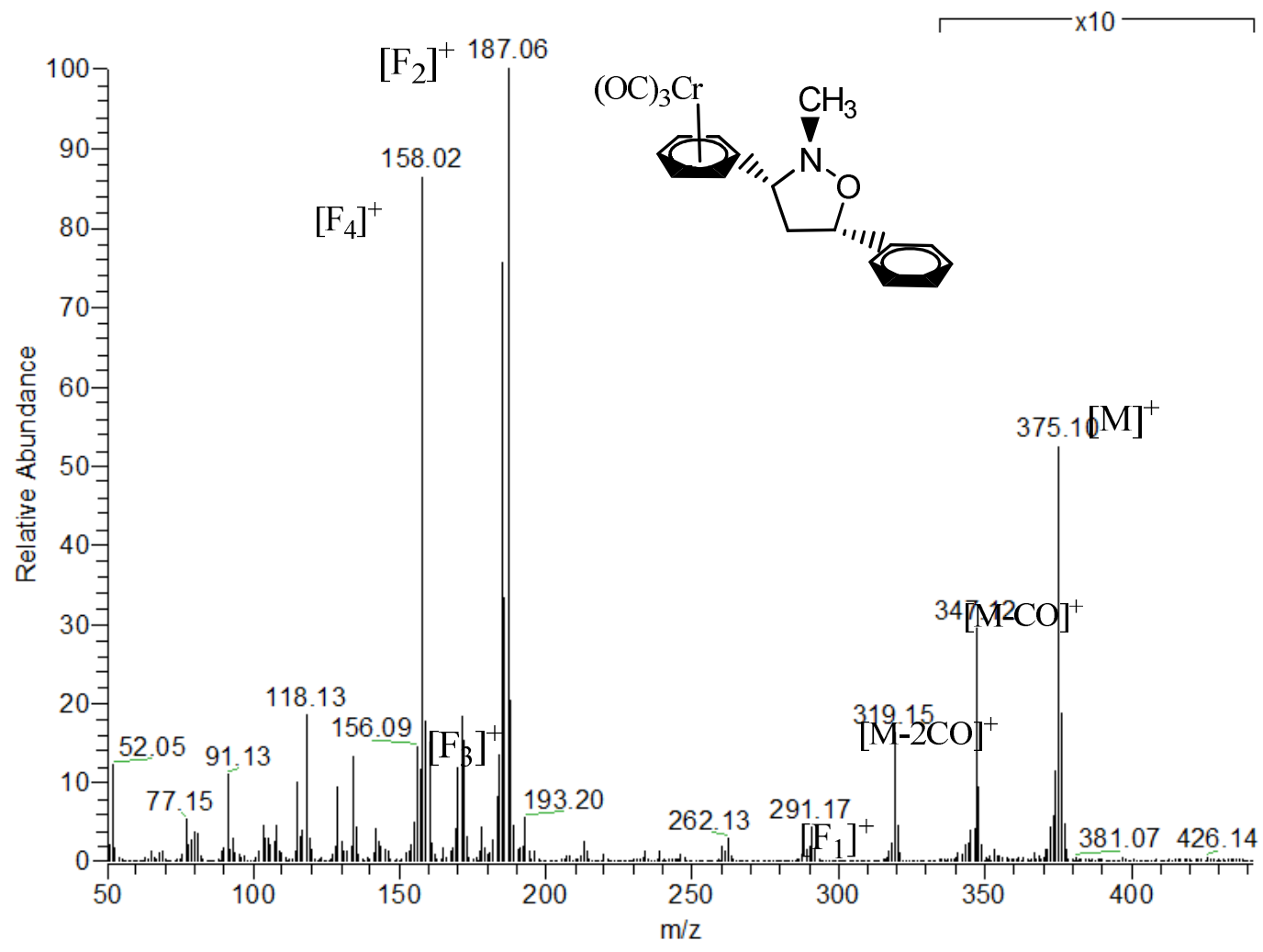

b)

Fig. 3. Mass-spectra of isoxazolidines cis-2a (a) and cis-3a (b) 
Data of mass-spectra of isoxazolidines cis-2-3

\begin{tabular}{|c|c|c|c|c|c|c|c|}
\hline \multirow{2}{*}{$\begin{array}{c}\text { Com- } \\
\text { pound }\end{array}$} & \multicolumn{7}{|c|}{ Characteristics of the ions: $\mathrm{m} / \mathrm{z}(\mathrm{I}, \%)$} \\
\cline { 2 - 8 } & {$[\mathrm{M}]^{+}$} & {$[\mathrm{M}-\mathrm{CO}]^{+}$} & {$[\mathrm{M}-2 \mathrm{CO}]^{+}$} & $\mathrm{F}_{1}$ & $\mathrm{~F}_{2}$ & $\mathrm{~F}_{3}$ & $\mathrm{~F}_{4}$ \\
\hline 2a & $375(1.2)$ & $347(0.3)$ & $319(13.2)$ & $291(31.2)$ & $187(100)$ & $171(16.0)$ & $158(31.1)$ \\
\hline $\mathbf{2 b}$ & $417(1.1)$ & $389(0.5)$ & $361(19.8)$ & $333(65.1)$ & $229(100)$ & $212(22.6)$ & - \\
\hline $\mathbf{2 c}$ & $437(1.8)$ & - & $381(5.7)$ & $353(47.2)$ & $249(82.1)$ & $233(57.6)$ & - \\
\hline 3a & $375(5.3)$ & $347(2.9)$ & $319(16.0)$ & $291(4.7)$ & $187(100)$ & $171(18.9)$ & $158(86.8)$ \\
\hline 3b & $417(5.0)$ & - & $361(11.3)$ & $333(62.3)$ & $229(100)$ & $212(32.1)$ & - \\
\hline 3c & $437(2.4)$ & - & $381(6.7)$ & $353(52.8)$ & $249(85.3)$ & $233(66.0)$ & - \\
\hline
\end{tabular}<smiles>O=C[PH2+]C1=CC=C[CH+]1</smiles>

$\left[\mathrm{F}_{4}\right]^{+}$

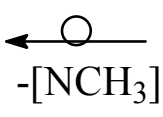

$\mathrm{Ph}^{*}$<smiles>C/C=N/[O-]</smiles>

$\left[\mathrm{F}_{2}\right]^{+}$<smiles>C[C+]C=NC=[Pb]</smiles>

$\left[\mathrm{F}_{3}\right]^{+}$

where $\mathrm{Ph}^{*}=\mathrm{C}_{6} \mathrm{H}_{5} \mathrm{Cr}$

\section{Scheme 5}

Similar to the example described above (complex 2a), tert-butyl (2b) and phenyl (2c) analogues of this compound completely copy the fragmentation of $\mathbf{2 a}$ up to formation of ions $\left[\mathrm{F}_{2}\right]^{+}$and $\left[\mathrm{F}_{3}\right]^{+}$, however, instead of the rearrangement process leading to $\left[\mathrm{F}_{4}\right]^{+}$, they are better characterized by: removal of isobutane (fragmentaion of $\mathbf{2 b}$, Scheme 6) and removal of nitrobenzene $\mathrm{C}_{6} \mathrm{H}_{5} \mathrm{NO}$ (fragmentation of $\mathbf{2 c}$, Scheme 7).

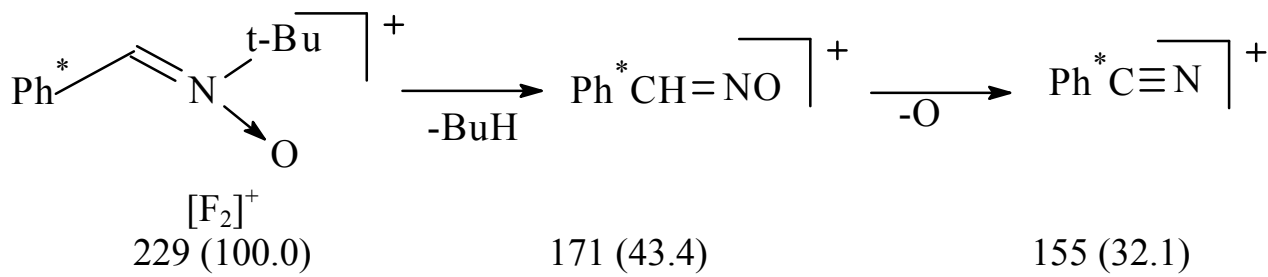

Scheme 6

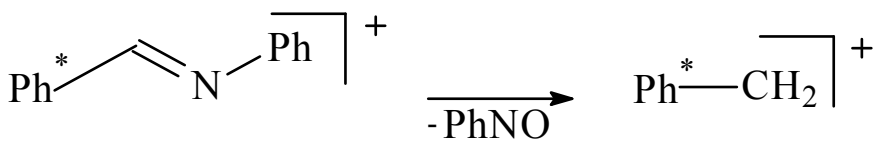

$\left[\mathrm{F}_{2}\right]^{+}$

$353(47.2)$

$143(72.6)$

where $\mathrm{Ph}^{*}=\mathrm{C}_{6} \mathrm{H}_{5} \mathrm{Cr}$

Scheme 7

It is of interest to compare the mass spectra of two isomeric compounds $\mathbf{2 a}$ and $\mathbf{3 a}$, which differ from each other by the arrangement of $\mathrm{Cr}(\mathrm{CO})_{3}$ groups in the complex (Fig. 3). As can be seen in Fig. 3, the mass number of ions have equal values, while the intensities of molecular ions in the mass spectra of 2a and 3a strongly differ. The fragmentation of isoxazolidine 3a is represented in Scheme 8.

Compounds $\mathbf{3 b}$ and $\mathbf{3} \mathbf{c}$ are fragmented according to the same scheme. Their mass spectra practically completely coincide with the mass spectra of the isomeric compounds $\mathbf{2 b}$ and $\mathbf{2 c}$ (Table 4). Unfortunate- 
ly, we failed to get satisfactory mass spectra for binuclear complexes $\mathbf{4 a - c}$, because of lesser stability and low volatility of these compounds. They all decomposed in the process of evaporation in the ion source of the mass spectrometer.<smiles>C=C[CH+]C</smiles>

$[\mathrm{M}]^{+}$

375 (5.3)

where $\mathrm{Ph}^{*}=\mathrm{C}_{6} \mathrm{H}_{5} \mathrm{Cr}$
$\left[\mathrm{F}_{3}\right]^{+}$

171 (18.9)<smiles>CN([O-])C=[P+]</smiles>

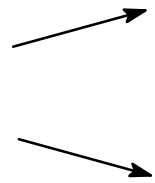

$\left[\mathrm{F}_{4}\right]^{+}$

158 (86.8)
$\left[\mathrm{F}_{2}\right]^{+}$ 187 (100.0)

Scheme 8

\section{Experimental}

The synthesis of $\eta^{6}$-(arene)tricarbonylchromium complexes of isoxazolidines (2a-c - $\mathbf{4 a - c )}$ was carried out according to the procedure described in papers $[4,5]$. IR spectra were registered on the "Infralume FT-801" spectrometer in the range $4000-400 \mathrm{~cm}^{-1}$ in $\mathrm{KBr}$ pellets, cyclohexane and $\mathrm{CCl}_{4} \mathrm{Solutions}$ ${ }^{1} \mathrm{H}$ NMR spectra were registered on the "Bruker DPX 200" and "Bruker Avance DPX 400" spectrometers, with acetone- $\mathrm{d}_{6}$ as the solvent. Field tailoring was conducted at the signal of deuterium nuclei of the solvent. Mass spectrometric analysis was performed on DSQ II mass spectrometer: a few micrograms of the studied substance was placed into a test microtube of the direct injection system, which was introduced through the vacuum lock directly into the ion source of the spectrometer. The microtube was heated from 50 to $450{ }^{\circ} \mathrm{C}$ at the rate $100^{\circ} \mathrm{C} / \mathrm{min}$, mass spectra were registered in the range of mass numbers 50-700 under the energy of ionizing electrons equaling $70 \mathrm{eV}$.

Cis-2-methyl-3-( $\eta^{6}$-phenyltricarbonylchromium)-5-phenylisoxzaolidine (cis-2a). Yield 25\%, m.p. 94-95 ${ }^{\circ} \mathrm{C}$. IR spectrum (KBr), v/ $\mathrm{cm}^{-1}$ : 2952, $2839(v(\mathrm{C}-\mathrm{H})), 1956,1875,1862(v(\mathrm{C} \equiv \mathrm{O})), 1458$, 1444, $1420(v(\mathrm{C}-\mathrm{C})), 764,702,664,630\left(\omega\left(\mathrm{C}_{\mathrm{Ar}} \mathrm{H}\right)\right)$. IR spectrum $\left(\mathrm{n}-\mathrm{C}_{6} \mathrm{H}_{14}\right), v / \mathrm{cm}^{-1}: 1979,1912$ $(v(\mathrm{C} \equiv \mathrm{O}))$. IR spectrum $\left(\mathrm{CCl}_{4}\right), v / \mathrm{cm}^{-1}: 1975,1905(v(\mathrm{C} \equiv \mathrm{O})) .{ }^{1} \mathrm{H}$ NMR spectrum $(400 \mathrm{MHz}, \delta, \mathrm{ppm}$, $J / \mathrm{Hz}$ ): 2.28 (t.d., 1H, $\mathrm{HC}(4), J=12.6, J=7.6) ; 2.90$ (s, 3H, $\mathrm{CH}_{3}$ ); 3.24 (t.d., 1H, $\left.\mathrm{HC}(4), J=12.6, J=7.6\right)$, 3,78 (t, 1H, HC(3), J=7.6); 5.23 (d, 1H, C(3)PhCr, J=6.4,); 5.27-5.38 (m, 4H, C(3)PhCr, HC(5)); 5.67 $(\mathrm{d}, 1 \mathrm{H}, \mathrm{C}(3) \mathrm{PhCr}, J=6.4)$; 7.27-7.38 (m, 5H, PhN). Mass spectrum (EI, $70 \mathrm{eV}, \mathrm{m} / \mathrm{z}\left(\mathrm{I}_{\mathrm{rel}}(\%)\right): 375[\mathrm{M}]^{+}$

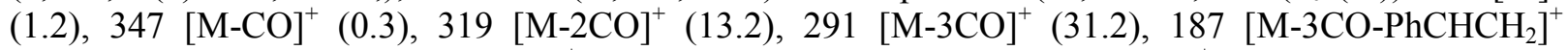
(100.0), $171\left[\mathrm{M}-3 \mathrm{CO}-\mathrm{PhCHCH}_{2}-\mathrm{O}\right]^{+}$(16.0), $158\left[\mathrm{M}-3 \mathrm{CO}-\mathrm{PhCHCH}_{2}-\mathrm{NCH}_{3}\right]^{+}$(31.1), 118 [M-3CO$\left.\mathrm{PhCHCH}_{2}-\mathrm{Cr}-\mathrm{H}-\mathrm{O}\right]^{+}$(12.1), $91\left[\mathrm{PhCH}_{2}\right]^{+}(7.8), 52\left[\mathrm{Cr}^{+}\right](9,0)$.

Cis-2-tertbutyl-3-( $\eta^{6}$-phenyltricarbonylchromium)-5-phenylisoxazolidine (cis-2b). Yield 30\%, m.p. $40-41{ }^{\circ} \mathrm{C}$. IR spectrum $(\mathrm{KBr}), v / \mathrm{cm}^{-1}$ : 3070, 3033, 2984, 2917, $2850(v(\mathrm{C}-\mathrm{H})) ; 1961,1885,1871$ $(v(C \equiv O)) ; 1531,1455,1421(v(C-C)) ; 758,697,663,632\left(\omega\left(\mathrm{C}_{\mathrm{Ar}}-\mathrm{H}\right)\right)$. IR spectrum $\left(\mathrm{n}-\mathrm{C}_{6} \mathrm{H}_{14}\right), v / \mathrm{cm}^{-1}$ : 1976, 1909, $1903(v(\mathrm{C} \equiv \mathrm{O}))$. IR spectrum $\left(\mathrm{CCl}_{4}\right), v / \mathrm{cm}^{-1}: 1972,1901(\mathrm{v}(\mathrm{C} \equiv \mathrm{O}))$. ${ }^{1} \mathrm{H}$ NMR spectrum $(200$ $\mathrm{MHz}, \delta$, ppm, J/Hz): $1.21\left(\mathrm{~s}, 9 \mathrm{H}, \mathrm{t}-\mathrm{C}_{4} \mathrm{H}_{9}\right) ; 2.18-2.52$ (m, $\left.1 \mathrm{H}, \mathrm{HC}(4)\right) ; 3.20-3.44$ (m, $\left.1 \mathrm{H}, \mathrm{HC}(4)\right) ; 4.53$ (d.d, $1 \mathrm{H}, \mathrm{HC}(3), J=8.5, J=6.0) ; 5.26$ (t, $1 \mathrm{H}, \mathrm{HC}(5), J=7.6) ; 5.43-5.59$ (m, $2 \mathrm{H}, m-\mathrm{C}(3) \mathrm{PhCr}) ; 5.66$ (t, $1 \mathrm{H}, n-\mathrm{C}(3) \mathrm{PhCr}, J=6.3$ ); 5.91 (br. d, $1 \mathrm{H}, o-\mathrm{C}(3) \mathrm{PhCr}, J=6.5) ; 6.10$ (br. d, $1 \mathrm{H}, o-\mathrm{C}(3) \mathrm{PhCr}, J=$ $6.5)$; 7.04-7.66 (m, $5 \mathrm{H}, \mathrm{C}(5) \mathrm{Ph})$. Mass spectrum (EI, $\left.70 \mathrm{eV}, \mathrm{m} / \mathrm{z}\left(\mathrm{I}_{\mathrm{rel} .}, \%\right)\right): 417$ [M] ${ }^{+}$(1.1), 389 [M-CO] $(0.5), 361\left[\mathrm{M}-2 \mathrm{CO}^{+}\right.$(19.8), $333\left[_{\mathrm{M}-3 \mathrm{CO}]^{+}}\right.$(65.1), $229\left[\mathrm{M}-3 \mathrm{CO}-\mathrm{PhCHCH}_{2}\right]^{+}(100.0), 212[\mathrm{M}-3 \mathrm{CO}-$ $\left.\mathrm{PhCHCH}_{2}-\mathrm{O}\right]^{+}$(22.6), $171\left[\mathrm{M}-3 \mathrm{CO}-\mathrm{PhCHCH}_{2}-\mathrm{C}_{4} \mathrm{H}_{9}-\mathrm{H}\right]^{+}$(43.4), 155 [M-3CO-PhCHCH $\left.2-\mathrm{O}-\mathrm{C}_{4} \mathrm{H}_{9}-\mathrm{H}\right]^{+}$ (32.1), $129[\mathrm{PhCr}]^{+}(12.0), 93\left[\mathrm{C}_{6} \mathrm{H}_{5} \mathrm{CH}_{2} \mathrm{H}_{2}\right]^{+}(13.0), 52[\mathrm{Cr}]^{+}(8.7)$.

Cis-3-( $\eta^{6}$-phenyltricarbonylchromium)-2,5-diphenylisoxazolidine (cis-2c). Yield 62\%, m.p. 121-122 ${ }^{\circ} \mathrm{C}$. IR spectrum $(\mathrm{KBr}), v / \mathrm{cm}^{-1}: 2983(v(\mathrm{C}-\mathrm{H})) ; 1957,1882,1865(\mathrm{v}(\mathrm{C} \equiv \mathrm{O})) ; 1594,1488,1454$ 


\section{Organometallic chemistry}

$(v(C-C)) ; 763,702,656,632\left(\omega\left(C_{A r}-H\right)\right)$. IR spectrum $\left(n-C_{6} H_{14}\right), v / \mathrm{cm}^{-1}: 1980,1914,1905(v(C \equiv O))$. IR spectrum $\left(\mathrm{CCl}_{4}\right), v / \mathrm{cm}^{-1}: 1976,1905(\mathrm{v}(\mathrm{C} \equiv \mathrm{O})) .{ }^{1} \mathrm{H}$ NMR spectrum $(200 \mathrm{MHz}, \delta, \mathrm{ppm}, J / \mathrm{Hz}): 2.39$ (d.d.d, $1 \mathrm{H}, \mathrm{HC}(4), J=12.8,9.0,5.0) ; 3.15-3.53$ (m, $1 \mathrm{H}, \mathrm{HC}(4)$ ); 5.04 (d.d, $1 \mathrm{H}, \mathrm{HC}(3), J=9.0, J=$ 5.0); 5.13-5.33 (m, $1 \mathrm{H}, \mathrm{HC}(5)$ ); 5.57-5.80 (m, $3 \mathrm{H}, \mathrm{C}(3) \mathrm{PhCr}$ ); 5.91 (br. d, $1 \mathrm{H}, o-\mathrm{C}(3) \mathrm{PhCr}, J=5.9$ ); 6.05-6.19 (m, $1 \mathrm{H}, \mathrm{C}(3) \mathrm{PhCr}$ ); 6.99 (t, $1 \mathrm{H}, n-\mathrm{PhN}, J=7.0)$; 7.11-7.58 (m, $9 \mathrm{H}, \mathrm{PhN}, \mathrm{PhC}(5)$ ). Mass spectrum (EI, $\left.70 \mathrm{eV}, \mathrm{m} / \mathrm{z}\left(\mathrm{I}_{\text {rel. }} \%\right)\right): 437[\mathrm{M}]^{+}(1.8), 381\left[_{\mathrm{M}-2 \mathrm{CO}]^{+}}(5.7), 353[\mathrm{M}-3 \mathrm{CO}]^{+}\right.$(47.2), 249 [M$\left.3 \mathrm{CO}-\mathrm{PhCHCH}_{2}\right]^{+}$(82.1), 247 [M-3CO-PhCHCH $\left.2-2 \mathrm{H}\right]^{+}$(100.0), 233 [M-3CO-PhCHCH $\left.2-\mathrm{O}\right]^{+}$(57.6), 180 $\left[\mathrm{M}-3 \mathrm{CO}-\mathrm{PhCHCH}{ }_{2}-\mathrm{O}-\mathrm{Cr}-\mathrm{H}\right]^{+}$(11.3), 143 [M-3CO-PhCHCH-O-NPh] ${ }^{+}$(72.6), $91\left[\mathrm{C}_{6} \mathrm{H}_{5} \mathrm{CH}_{2}\right]^{+}$(9.3), 52 $[\mathrm{Cr}]^{+}(8.7)$.

Cis-2-methyl-5-( $\eta^{6}$-phenyltricarbonylchromium)-3-phenylisoxazolidine (cis-3a). Yield $66 \%$, m.p. 91-92 ${ }^{\circ} \mathrm{C}$. IR spectrum $(\mathrm{KBr}), v / \mathrm{cm}^{-1}$ : 3020, 2992, $2877(\mathrm{v}(\mathrm{C}-\mathrm{H})) ; 1955,1894,1875(\mathrm{v}(\mathrm{C} \equiv \mathrm{O}))$; 1454, $1384(v(\mathrm{C}-\mathrm{C})) ; 771,660,633\left(\omega\left(\mathrm{C}_{\mathrm{Ar}}-\mathrm{H}\right)\right)$. IR spectrum $\left(\mathrm{n}-\mathrm{C}_{6} \mathrm{H}_{14}\right), v / \mathrm{cm}^{-1}: 1980,1912(v(\mathrm{C} \equiv \mathrm{O}))$. IR spectrum $\left(\mathrm{CCl}_{4}\right), v / \mathrm{cm}^{-1}: 1977,1906(v(\mathrm{C} \equiv \mathrm{O})) .{ }^{1} \mathrm{H}$ NMR spectrum $(400 \mathrm{MHz}, \delta, \mathrm{ppm}, J / \mathrm{Hz}): 2.29$ (d.d.d, $1 \mathrm{H}, \mathrm{HC}(4), J=12.6, J=9.5, J=6.3) ; 2.57$ (s, 3H, $\mathrm{CH}_{3}$ ); 3.22-3.29 (m, $1 \mathrm{H}, \mathrm{HC}(4)$ ); 3.71 (br. t, $1 \mathrm{H}, \mathrm{HC}(3), J=8.4$ ); 4.98 (d.d, $1 \mathrm{H}, \mathrm{HC}(5), J=8.5, J=6.3) ; 5.52-5.59$ (m, $1 \mathrm{H}, \mathrm{C}(5)-m-\mathrm{PhCr}) ; 5.66$ (d, $2 \mathrm{H}, \mathrm{C}(5)-o-\mathrm{PhCr}, J=3.8) ; 5.71$ (t, $1 \mathrm{H}, \mathrm{C}(5)-m-\mathrm{PhCr}, J=6.4) ; 5.95$ (d, $1 \mathrm{H}, \mathrm{C}(5)-p$-PhCr, $J=6.4$ ); 7.29 (d, $1 \mathrm{H}, p-\mathrm{PhC}(3), J=7.0) ; 7.34$ (d.d, $2 \mathrm{H}, m-\mathrm{PhC}(3), J=7.3, J=7.0) ; 7.39$ (br. d, $2 \mathrm{H}, o-\mathrm{PhC}(3), J$ = 7.3). Mass spectrum (EI, $70 \mathrm{eV}, \mathrm{m} / \mathrm{z}\left(\mathrm{I}_{\text {rel. }} \%\right.$ ) $): 375[\mathrm{M}]^{+}(5.3), 347[\mathrm{M}-\mathrm{CO}]^{+}(2.9), 319[\mathrm{M}-2 \mathrm{CO}]^{+}$ (16.0), $291[\mathrm{M}-3 \mathrm{CO}]^{+}$(4.7), 187 [M-3CO-PhCHCH $]^{+}$(100.0), 171 [M-3CO-PhCHCH $\left._{2}-\mathrm{O}\right]^{+}$(18.9), 158 $\left[\mathrm{M}-3 \mathrm{CO}-\mathrm{PhCHCH}{ }_{2}-\mathrm{NCH}_{3}\right]^{+}$(86.8), 134 [M-3CO-PhCHCH$\left.{ }_{2}-\mathrm{Cr}-\mathrm{H}\right]^{+}$(13.2), 118 [M-3CO-PhCHCH ${ }_{2}-\mathrm{Cr}-$ $\mathrm{H}-\mathrm{O}]^{+}$(17.9), $91\left[\mathrm{C}_{6} \mathrm{H}_{5} \mathrm{CH}_{2}\right]^{+}(10.8), 77[\mathrm{Ph}]^{+}$(5.2), $52[\mathrm{Cr}]^{+}(11.8)$.

Trans-2-methyl-5-( $\eta^{6}$-phenyltricarbonylchromium)-3-phenylisoxazolidine (trans-3a). Yield $14 \%$, m.p. $112-113{ }^{\circ} \mathrm{C}$. IR spectrum $(\mathrm{KBr}), v / \mathrm{cm}^{-1}: 1956,1895,1878(\mathrm{v}(\mathrm{C} \equiv \mathrm{O})) ; 1384(\mathrm{v}(\mathrm{C}-\mathrm{C})) ; 706$, 661, 633( $\left.\omega\left(\mathrm{C}_{\mathrm{Ar}}-\mathrm{H}\right)\right) .{ }^{1} \mathrm{H}$ NMR spectrum $(400 \mathrm{MHz}, \delta, \mathrm{ppm}, J / \mathrm{Hz}): 2.59\left(\mathrm{~s}, 3 \mathrm{H}, \mathrm{CH}_{3} \mathrm{~N}\right) ; 2.62-2.79(\mathrm{~m}, 2$ $\mathrm{H}, \mathrm{HC}(4)) ; 3.13$ (d.d, $1 \mathrm{H}, \mathrm{HC}(3), J=10.8, J=5.3) ; 4.93$ (br. t, $1 \mathrm{H}, \mathrm{HC}(5), J=7.2) ; 5.57-5.71(\mathrm{~m}, 3 \mathrm{H}$, $\mathrm{C}(5) \mathrm{PhCr}) ; 5.78$ (t, $2 \mathrm{H}, \mathrm{C}(5) \mathrm{PhCr}, J=7.7) ; 7.30$ (d, $1 \mathrm{H}, o-\mathrm{PhC}(3), J=7.0) ; 7.36-7.52$ (m, $4 \mathrm{H}, o-, m-$, $p$-PhC(3)).

Cis-2-tertbutyl-5-( $\eta^{6}$-phenyltricarbonylchromium)-3-phenylisoxazolidine (cis-3b). Yield 47\%, m.p. 104-105 ${ }^{\circ} \mathrm{C}$. IR spectrum $(\mathrm{KBr}), v / \mathrm{cm}^{-1}: 3079,2981,2921(v(\mathrm{C}-\mathrm{H})) ; 1951,1885,1872(v(\mathrm{C} \equiv \mathrm{O}))$; $1632\left(v\left(\mathrm{C}-\mathrm{C}_{\mathrm{Ar}}\right)\right) ; 1490,1455(v(\mathrm{C}-\mathrm{C})) ; 767,707,660,633\left(\omega\left(\mathrm{C}_{\mathrm{Ar}} \mathrm{H}\right)\right)$. IR spectrum $\left(\mathrm{n}-\mathrm{C}_{6} \mathrm{H}_{14}\right), v / \mathrm{cm}^{-1}$ : 1979, $1911(v(\mathrm{C} \equiv \mathrm{O}))$. IR spectrum $\left(\mathrm{CCl}_{4}\right), v / \mathrm{cm}^{-1}: 1975,1904(v(\mathrm{C} \equiv \mathrm{O})) .{ }^{1} \mathrm{H}$ NMR spectrum $(200 \mathrm{MHz}$, $\delta$, ppm, $J / \mathrm{Hz}$ ): 1.08 (s, $\left.9 \mathrm{H}, \mathrm{t}-\mathrm{C}_{4} \mathrm{H}_{9}\right) ; 2.19$ (br. d.t, $1 \mathrm{H}, \mathrm{HC}(4), J=12.0, J=9.0$ ); 3.16 (br. d.t, $1 \mathrm{H}$, $\mathrm{HC}(4), J=12.0, J=7.0$ ); 4.49 (d.d, $1 \mathrm{H}, \mathrm{HC}(3), J=9.0, J=7.5$ ); 4.88 (d.d, $1 \mathrm{H}, \mathrm{HC}(5), J=8.2, J=$ 7.0); 5.58 (m, $2 \mathrm{H}, m-\mathrm{C}(5) \mathrm{PhCr}) ; 5.63(\mathrm{~d}, 1 \mathrm{H}, o-\mathrm{C}(5) \mathrm{PhCr}, J=4.0) ; 5.71$ (t, $1 \mathrm{H}, p-\mathrm{C}(5) \mathrm{PhCr}, J=6.0)$; 5.99 (d, $1 \mathrm{H}, o-\mathrm{C}(5) \mathrm{PhCr}, J=6.0) ; 7.32(\mathrm{~m}, 3 \mathrm{H}, m-, p-\mathrm{PhC}(3)) ; 7.48$ (d, $2 \mathrm{H}, o-\mathrm{PhC}(3), J=7.0)$. Mass spectrum (EI, $\left.70 \mathrm{eV}, \mathrm{m} / \mathrm{z}\left(\mathrm{I}_{\text {rel. }}, \%\right)\right): 417[\mathrm{M}]^{+}(5.0), 361[\mathrm{M}-2 \mathrm{CO}]^{+}(11.3), 333[\mathrm{M}-3 \mathrm{CO}]^{+}(62.3), 229[\mathrm{M}-$ $\left.3 \mathrm{CO}-\mathrm{PhCHCH}_{2}\right]^{+}$(100.0), 212 [M-3CO-PhCHCH$\left.{ }_{2}-\mathrm{O}\right]^{+}$(32.1), $172\left[\mathrm{M}-3 \mathrm{CO}-\mathrm{PhCHCH}_{2}-\mathrm{C}_{4} \mathrm{H}_{9}\right]^{+}$(41.5), $155\left[\mathrm{M}-3 \mathrm{CO}-\mathrm{PhCHCH}_{2}-\mathrm{O}-\mathrm{C}_{4} \mathrm{H}_{9}-\mathrm{H}\right]^{+}$(33.0), $129[\mathrm{PhCr}]^{+}$(14.2), $91\left[\mathrm{C}_{6} \mathrm{H}_{5} \mathrm{CH}_{2}\right]^{+}$(5.2), $52[\mathrm{Cr}]^{+}$(13.2).

Cis-5-( $\eta^{6}$-phenyltricarbonylchromium)-2,3-diphenylisoxazolidine (cis-3c). Yield 42\%, m.p. 112-113 ${ }^{\circ} \mathrm{C}$. IR spectrum (KBr), $v / \mathrm{cm}^{-1}: 3092,2916,2923,2849$ (v(C-H)); 1970, 1904, $1857(v(\mathrm{C} \equiv \mathrm{O})$; $1595,1540,1489(v(\mathrm{C}-\mathrm{C})) ; 761,699,663,622\left(\omega\left(\mathrm{C}_{\mathrm{Ar}}-\mathrm{H}\right)\right)$. IR spectrum $\left(\mathrm{n}-\mathrm{C}_{6} \mathrm{H}_{14}\right), v / \mathrm{cm}^{-1}: 1981,1914$ $(v(\mathrm{C} \equiv \mathrm{O}))$. IR spectrum $\left(\mathrm{CCl}_{4}\right), v / \mathrm{cm}^{-1}: 1978,1907(v(\mathrm{C} \equiv \mathrm{O})) .{ }^{1} \mathrm{H}$ NMR spectrum $(200 \mathrm{MHz}, \delta$, ppm, $J / \mathrm{Hz}$ ): 2.37 (d.t, $1 \mathrm{H}, \mathrm{HC}(4), J=12.4, J=8.8, J=7.2$ ); 3.37 (d.t, $1 \mathrm{H}, \mathrm{HC}(4), J=12.4, J=7.2, J=6.0$ ); 5.00 (br. t, $2 \mathrm{H}, \mathrm{HC}(3), \mathrm{HC}(5), J=7.2) ; 5.50-5.80$ (m, $4 \mathrm{H}, o-, m-, p-\mathrm{C}(5) \mathrm{PhCr}$ ); 5.85 (d, $1 \mathrm{H}, o-$ $\mathrm{C}(5) \mathrm{PhCr}, J=6.0) ; 6.94$ (t, $1 \mathrm{H}, p-\mathrm{PhN}, J=7.2) ; 7.11(\mathrm{~d}, 2 \mathrm{H}, o-\mathrm{PhN}, J=3.8) ; 7.26$ (m, $3 \mathrm{H}, m-\mathrm{PhN}, p-$ $\mathrm{PhC}(3)) ; 7.40(\mathrm{~m}, 2 \mathrm{H}, m-\mathrm{PhC}(3)) ; 7.58$ (d, $2 \mathrm{H}, o-\mathrm{PhC}(3), J=7.4)$. Mass spectrum (EI, $70 \mathrm{eV}, \mathrm{m} / \mathrm{z}$ $\left(\mathrm{I}_{\text {rel. }, \%)} \%\right): 437[\mathrm{M}]^{+}(2.4), 381[\mathrm{M}-2 \mathrm{CO}]^{+}(6.7), 353[\mathrm{M}-3 \mathrm{CO}]^{+}$(52.8), $249\left[\mathrm{M}-3 \mathrm{CO}-\mathrm{PhCHCH}_{2}\right]^{+}$(84.9), $249\left[\mathrm{M}-3 \mathrm{CO}-\mathrm{PhCHCH}_{2}\right]^{+}$(85.3), $247\left[\mathrm{M}-3 \mathrm{CO}-\mathrm{PhCHCH}_{2}-2 \mathrm{H}\right]^{+}(100.0), 233$ [M-3CO-PhCHCH $\left.{ }_{2}-\mathrm{O}\right]^{+}$ (66.0), $180 \quad\left[\mathrm{M}-3 \mathrm{CO}-\mathrm{PhCHCH}{ }_{2}-\mathrm{O}-\mathrm{Cr}-\mathrm{H}\right]^{+} \quad$ (26.4), $143 \quad[\mathrm{M}-3 \mathrm{CO}-\mathrm{PhCHCH}-\mathrm{O}-\mathrm{NPh}]^{+} \quad$ (62.2), 91 $\left[\mathrm{C}_{6} \mathrm{H}_{5} \mathrm{CH}_{2}\right]^{+}(16.5), 52[\mathrm{Cr}]^{+}(16.0)$.

Cis-2-methyl-3,5-bis $\left(\eta^{6}\right.$-phenyltricarbonylchromium)isoxazolidine (cis-4a). Yield $20 \%$, m.p. 155-156 ${ }^{\circ} \mathrm{C}$. IR spectrum (KBr), $v / \mathrm{cm}^{-1}: 2958,2919,2863(v(\mathrm{C}-\mathrm{H})) ; 1953,1885,1877(v(\mathrm{C} \equiv \mathrm{O})) ; 1636$, 1493, $1454(v(\mathrm{C}-\mathrm{C})) ; 699,662,633\left(\omega\left(\mathrm{C}_{\mathrm{Ar}} \mathrm{-H}\right)\right) .{ }^{1} \mathrm{H}$ NMR spectrum $(200 \mathrm{MHz}, \delta, \mathrm{ppm}, J / \mathrm{Hz}): 2.08$ (s, 3 $\mathrm{H}, \mathrm{CH}_{3} \mathrm{~N}$ ), 2.31 (d.t, $1 \mathrm{H}, \mathrm{HC}(4), J=12.6, J=7.1$ ), 3.43 (d.t, $1 \mathrm{H}, \mathrm{HC}(4), J=12.6, J=8.1$ ), 3.83 (br. t, 1 
$\mathrm{H}, \mathrm{HC}(3), J=8.1), 5.07$ (t, $1 \mathrm{H}, \mathrm{HC}(5), J=7.1), 5.50-5.75$ (m, $8 \mathrm{H}, \mathrm{PhCr}), 5.75-5.91$ (m, $8 \mathrm{H}, \mathrm{PhCr}$ ). Mass spectrum (EI, $\left.70 \mathrm{eV}, \mathrm{m} / \mathrm{z}\left(\mathrm{I}_{\mathrm{rel}} \%\right)\right): 455[\mathrm{M}-2 \mathrm{CO}]^{+}(12.5), 427[\mathrm{M}-3 \mathrm{CO}]^{+}(25.0), 343[\mathrm{M}-6 \mathrm{CO}]^{+}$ (100.0), 239 [M-6CO-PhCHCH$]^{+}$(90.1), 212 (22.2), 187 [M-6CO-PhCHCH $\left.2-C r\right]^{+}$(40.3), 170 (34.0), 158 (25.0), 120 (38.9), 97 (49.3), 85 (23.6), 52 [Cr $]^{+}(20.1)$.

Cis-2-tertbutyl-3,5-bis $\left(\eta^{6}\right.$-phenyltricarbonylchromium)isoxazolidine (cis-4b). Yield 36\%, m.p. 136-137 ${ }^{\circ} \mathrm{C}$. IR spectrum $(\mathrm{KBr}), v / \mathrm{cm}^{-1}: 2918,2877(v(\mathrm{C}-\mathrm{H})) ; 1963,1886,1865(v(\mathrm{C} \equiv \mathrm{O}) ; 1633,1462$, $1408(v(\mathrm{C}-\mathrm{C})) ; 663,632,533\left(\omega\left(\mathrm{C}_{\mathrm{Ar}} \mathrm{H}\right)\right) .{ }^{1} \mathrm{H}$ NMR spectrum $(200 \mathrm{MHz}, \delta, \mathrm{ppm}, \mathrm{J} / \mathrm{Hz}): 1.20(\mathrm{~s}, 9 \mathrm{H}, \mathrm{t}-$ $\left.\mathrm{C}_{4} \mathrm{H}_{9}\right), 2.26-2.50(\mathrm{~m}, 1 \mathrm{H}, \mathrm{HC}(4)), 3.14-3.70$ (m, $\left.1 \mathrm{H}, \mathrm{HC}(4)\right), 4.51$ (d.d, $\left.1 \mathrm{H}, \mathrm{HC}(3), J=7.6, J=6.1\right)$, 4.99 (t, $1 \mathrm{H}, \mathrm{HC}(5) J=7.1), 5.39-5.73$ (m, $7 \mathrm{H}, \mathrm{PhCr}), 5.79$ (d, $1 \mathrm{H}, \mathrm{PhCr}, J=6.1), 5.95$ (d, $1 \mathrm{H}, \mathrm{PhCr}, J$

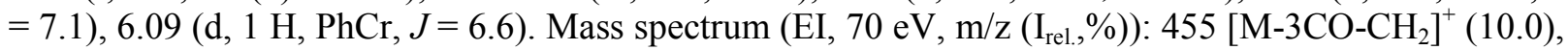
$427\left[\mathrm{M}-4 \mathrm{CO}-\mathrm{CH}_{2}\right]^{+}$(24.8), 343 (100.0), 239 (94.2), 212 (24.8), 187 (29.2), 170 (30.7), 158 (21.2), 125 (30.1), $111(42.3), 97(58.4), 85(30.1), 52[\mathrm{Cr}]^{+}(16.1)$.

Cis-3,5-bis $\left(\eta^{6}\right.$-phenyltricarbonylchromium)-2-phenylisoxazolidine (cis-4c). Yield 38\%. m.p. 132-133 ${ }^{\circ} \mathrm{C}$. IR spectrum (KBr), $v / \mathrm{cm}^{-1}: 2874,2723(v(\mathrm{C}-\mathrm{H})) ; 1961,1887,1870(v(\mathrm{C} \equiv \mathrm{O}) ; 1636,1487$ $(v(\mathrm{C}-\mathrm{C})) ; 661,631,536\left(\omega\left(\mathrm{C}_{\mathrm{Ar}}-\mathrm{H}\right)\right) .{ }^{1} \mathrm{H}$ NMR spectrum $(200 \mathrm{MHz}, \delta, \mathrm{ppm}, \mathrm{J} / \mathrm{Hz}): 2.41$ (d.d.d, $1 \mathrm{H}$, $\mathrm{HC}(4), J=12.6, J=8.6, J=4.6), 3.40$ (d.d.d, $1 \mathrm{H}, \mathrm{HC}(4), J=12.6, J=8.6, J=7.6), 4.82-5.19$ (m, 2 H, $\mathrm{HC}(3), \mathrm{HC}(5)), 5.50-5.76$ (m, $7 \mathrm{H}, \mathrm{PhCr}$ ), 5.83 (br. d, $1 \mathrm{H}, \mathrm{PhCr}, J=6.6$ ), 5.92 (br. d, $1 \mathrm{H}, \mathrm{PhCr}, J=$ 5.6), 6.05-6.15 (br. d, $1 \mathrm{H}, \mathrm{PhCr}), 6.88-7.09$ (m, $1 \mathrm{H}, \mathrm{PhN}), 7.09-7.46$ (m, $4 \mathrm{H}, \mathrm{PhN})$. Mass spectrum

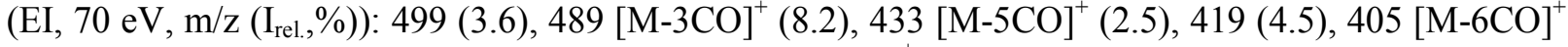
(38.4), 387 (22.4), 335 (100), 299 [M-6CO-PhCHCH$\left.{ }_{2}-2 \mathrm{H}\right]^{+}$(31.5), 260 (65.9), 233 (34.0), 180 (21.0), 129 (18.8), 93 (31.9), $77[\mathrm{Ph}]^{+}(13.0), 52[\mathrm{Cr}]^{+}(23.2)$.

\section{Conclusion}

With the use of 1,3-dipolar cycloaddition reactions the series of $\eta^{6}$-(arene)tricarbonylchromium complexes of isoxazolidines has been obtained. In the IR spectra of all obtained tricarbonylchromium complexes two strong (occasionally splitted) bands in the area of carbonyl vibrations are observed, which correlate to $\mathrm{Cr}(\mathrm{CO})_{3}$ groups. Difference in position of these bands in relation to $\mathrm{C}_{6} \mathrm{H}_{6} \mathrm{Cr}(\mathrm{CO})_{3}$ is consistent with the isoxazolidine system as a weak electron donor. It has been established that the study of ${ }^{1} \mathrm{H}$ NMR spectra is an excellent analytical method making it possible not only to determine qualitative composition of $\pi$-complexes, but also to open the way of unambiguous demonstration of their spatial diastereomer structure. The electron impact mass spectra resemble other mass spectra of monosubstituted derivatives of benzenetricarbonylchromium. Their fragmentation proceeds by way of sequential removal of three $\mathrm{CO}$ groups and retro disintegration of the isoxazolidine ring according to the general scheme. The main peak is the fragment of the molecular ion after the loss of three CO groups and removal of styrene. Other peaks of smaller intensity are the derivatives of this fragment.

\section{Acknowledgments}

The research has been carried out in the context of state assignment of the Russian Ministry of Education and Science (project No. 736) with the use of research equipment of the center "New materials and resource-saving technologies" in Lobachevsky NNSU (Ministry of Education and Science of the Russian Federation, project RFMEFI59414X0005).

\section{References}

1. Confalone P.N., Huie E.M. The [3+2] Nitrone-Olefin Cycloaddition Reaction in Organic Reactions. USA, John Willy and Sons, 1988, vol. 36, 173 p. DOI:10.1002/0471264180.or036.01

2. Huisgen F., Grashey R., Sauer J. Khimiya alkenov [The Chemistry of Alkenes]. Leningrad, Khimiya publ., 1969, pp. 444-534.

3. Gilchrist T., Storr R. Organicheskie reaktsii $i$ orbital'naya simmetriya [Organic Reactions and Orbital Symmetry]. Moscow, Mir publ., 1976, pp. 100-119.

4. Artemov A.N., Sazonova E.V., Mavrina E.A., Zarovkina N.Yu. [Synthesis of New $\eta^{6}-$ (arene)chromium Tricarbonyl Complexes of Isoxazolidines by 1,3-Dipolar Cycloaddition]. Russian Chemical Bulletin, 2012, no. 11, pp. 2076-2081. DOI: 10.1007/s11172-012-0290-4

5. Artemov A.N., Sazonova E.V., Zarovkina N.Yu. [1,3-Dipolar Cycloaddition Reactions of nitrone

$\eta^{6}$-(arene)tricarbonylchromium Complexes of Nitrones with Styrene and $\eta^{6}$ -




\title{
Organometallic chemistry
}

(styrene)tricarbonylchromium]. Russian Chemical Bulletin, 2013, no. 6, pp. 1382-1387. DOI: 10.1007/s11172-013-0197-8

6. Zarovkina N.Yu., Sazonova E.V., Artemov A.N., Fukin G.K. [Chemistry of Unsaturated Arenetricarbonylchromium Compounds. Part 1. Interaction of $\eta^{6}$-(arene)tricarbonylchromium Complexes of Nitrones with Methyl Phenylpropiolate]. Russian Chemical Bulletin, 2014, no. 4, pp.970-975. (in Russ.)

7. Raush M.D., Moses G.A., Zaiko E.S. Lipman Jr A.L. Organometallic $\pi$-Complexes. XX. The Preparation of Styrenetricarbonylchromium. J. Organomet. Chem., 1970, vol.23, pp. 185-190. DOI:10.1016/S0022-328X(00)92813-4

8. Aleksanyan V.T., Lokshin B.V. Itogi nauki i tekhniki. Seriya: Stroenie molekul i khimicheskaya svyaz'. T. 5: Kolebatel'nye spektry $\pi$-kompleksov perekhodnykh elementov [Results of Scientific and Technical Research. Ser. Molecular Structure and Chemical Bond. Vol. 5. Vibrational Spectra of $\pi$ Complexes of Transition Elements]. Moscow, VINITI Publ., 1976. 178 p.

9. Nesmeyanov A.N., Anisimov K.N., Lokshin B.V., Kolobova N.E., Makarov Yu.V. [Influence Transfer of Substituents through the Metal Atom in Cyclopentadienyltricarbonylmanganese $\mathrm{RC}_{5} \mathrm{H}_{4} \mathrm{Mn}(\mathrm{CO})_{3}$ Derivatives]. Proceedings of the USSR Academy of Sciences, 1967, vol. 176, no. 5, pp. 1082-1085. (in Russ.)

10. Bodrikov I. V., Grinval'd I.I., Artemov A. N., Bazhan L. I., Kalagaev I. Yu. Intramolecular $\mathrm{CO} \cdots \mathrm{H}$ Interaction in Arene(tricarbonyl)-chromium Complexes. Russian Journal of General Chemistry, 2010, vol. 80, № 1, pp. 20-22. DOI: 10.1134/S1070363210010032

Received 18 September 2015

\section{ХИМИЯ НЕПРЕДЕЛЬНЫХ АРЕНХРОМТРИКАРБОНИЛЬНЫХ СОЕДИНЕНИЙ. СООБЩЕНИЕ 3. СИНТЕЗ, ХАРАКТЕРИСТИКА И СПЕКТРОСКОПИЧЕСКОЕ ИССЛЕДОВАНИЕ П6-(АРЕН)ХРОМТРИКАРБОНИЛЬНЫХ ПРОИЗВОДНЫХ ИЗОКСАЗОЛИДИНОВ}

\author{
А.Н. Артемов, Е.В. Сазонова, Н.Ю. Заровкина, В.И. Фаерман \\ Нижегородский государственный университет им. Н.И. Лобачевского, \\ г. Нижний Новгород
}

Реакцией 1,3-диполярного циклоприсоединения получена широкая серия $\eta^{6}$-(арен)хромтрикарбонильных комплексов изоксазолидинов. Полученные соединения

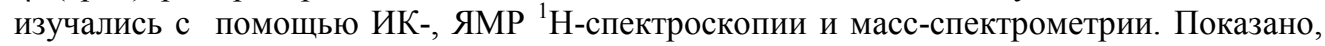
что $\mathrm{Cr}(\mathrm{CO})_{3}$-группа оказывает существенное влияние на структуру и спектральные характеристики синтезированных гетероциклов.

Ключевые слова: 1,3-диполярное ичилоприсоединение, нитрон, изоксазолидин, $\eta^{6}$-(арен)хромтрикарбонил, ИК-спектроскопия, ${ }^{1} H$ ЯМР ${ }^{1}$ H-спектроскопия, массспектрометрия.

\section{Литература}

1. Confalone, P.N. The [3+2] Nitrone-Olefin Cycloaddition Reaction in Organic Reactions / P.N. Confalone, E.M. Huie. - New York: John Willy and Sons, 1988. - V. 36. - 173 p.

2. Хьюзген, Ф. Химия алкенов / Ф. Хьюзген, Р. Грэши, Дж. Соейр. - Л.: Химия, 1969. C. $444-534$.

3. Джилкрист, Т. Органические реакции и орбитальная симметрия / Т. Джилкрист, Р. Сторр. - М.: Мир, 1976. - С. 100-119. 
4. Синтез новых $\eta^{6}$-(арен)хромтрикарбонильных комплексов изоксазолидинов реакцией 1,3диполярного циклоприсоединения / А.Н. Артемов, Е.В. Сазонова, Е.А. Маврина, Н.Ю. Заровкина // Известия АН. Серия «Химия». - 2012. - № 11. - С. 2059-2064.

5. Артемов, А.Н. Реакции 1,3-диполярного циклоприсоединения $\eta^{6}$-(арен)хромтрикарбонильных комплексов нитронов со стиролом и $\eta^{6}$-(стирол)хромтрикарбонилом / А.Н. Артемов, Е.В. Сазонова, Н.Ю. Заровкина // Известия АН. Серия «Химия». - 2013. - № 6. C. $1382-1387$.

6. Химия непредельных аренхромтрикарбонильных соединений. Сообщ. 1. Взаимодействие $\eta^{6}$-(арен) хромтрикарбонильных комплексов нитронов с метиловым эфиром фенилпропиоловой кислоты / Н.Ю. Заровкина, Е.В. Сазонова, А.Н. Артемов, Г.К. Фукин // Известия АН. Серия «Химия». - 2014. - № 4. - С. 970-975.

7. Organometallic $\pi$-Complexes. XX. The Preparation of Styrenetricarbonylchromium / M.D. Raush, G.A. Moser, E.S. Zaiko, Lipman Jr A.L. // J. Organomet. Chem. - 1970. - V. 23 - P. 185-190.

8. Алексанян, В.Т. Итоги науки и техники. Серия: Строение молекул и химическая связь. Т. 5: Колебательные спектры $\pi$-комплексов переходных элементов / В.Т. Алексанян, Б.В. Локшин. - М.: ВИНИТИ, 1976. - 178 с.

9. Передача влияния заместителей через атом металла в производных циклопентадиенилмарганецтрикарбонила $\mathrm{RC}_{5} \mathrm{H}_{4} \mathrm{Mn}(\mathrm{CO})_{3} /$ А.Н. Несмеянов, К.Н. Анисимов, Б.В. Локшин и др. // Докл. AH CCCP. - 1967. - T. 176. - № 5. - C. 1082-1085.

10. Внутримолекулярное взаимодействие $\mathrm{CO} \cdots \mathrm{H}$ в аренхромтрикарбонильных комплексах / И.В. Бодриков, И.И. Гринвальд, А.Н. Артемов и др. // Журн. общ. хим. - 2010. - Т. 80. - № 1. C. 24-26.

Артемов Александр Николаевич - доктор химических наук, профессор кафедры химии нефти (нефтехимического синтеза), Нижегородский государственный университет им. Н.И. Лобачевского. 603950, г. Нижний Новгород, пр. Гагарина, 23, корп. 5. E-mail: zarovkinan@mail.ru

Сазонова Елена Васильевна - ведущий инженер кафедры химии нефти (нефтехимического синтеза), Нижегородский государственный университет им. Н.И. Лобачевского. 603950, г. Нижний Новгород, пр. Гагарина, 23, корп. 5. E-mail: zarovkinan@mail.ru

Заровкина Наталия Юрьевна - аспирант химического факультета, Нижегородский государственный университет им. Н.И. Лобачевского. 603950, г. Нижний Новгород, пр. Гагарина, 23, корп. 5. E-mail: zarovkinan@mail.ru

Фаерман Владимир Исаакович - старший научный сотрудник НИИ химии, Нижегородский государственный университет им. Н.И. Лобачевского, 603950, г. Нижний Новгород, пр. Гагарина, 23, корп. 5. E-mail: vvllff@rambler.ru

Поступила в редакцию 18 сентября 2015 2.

\section{ОБРАЗЕЦ ЦИТИРОВАНИЯ}

Chemistry of Unsaturated Arenetricarbonylchromium Compounds. Part 3. Synthesis, Characteristics and Spectroscopic Research of H6-(Arene)Tricarbonylchromium Derivatives of Isoxazolidines / A.N. Artemov, E.V. Sazonova, N.Yu. Zarovkina, Faerman V.I. // Вестник ЮУрГУ. Серия «Химия». - 2015. - Т. 7, № 4. - С. 30-43. DOI: $10.14529 /$ chem 150405

\section{FOR CITATION}

Artemov A.N., Sazonova E.V., Zarovkina N.Yu., Faerman V.I. Chemistry of Unsaturated Arenetricarbonylchromium Compounds. Part 3. Synthesis, Characteristics and Spectroscopic Research of H6-(Arene)Tricarbonylchromium Derivatives of Isoxazolidines. Bulletin of the South Ural State University. Ser. Chemistry. 2015, vol. 7, no. 4, pp. 30-43. DOI: 10.14529/chem150405 